\title{
Editorial
}

\section{The EU AND CONSTITUTIONAL CHANGE: A RESEARCH PROPOSAL}

In their 'Deauville deal' of October 18, 2010, Chancellor Angela Merkel and President Nicolas Sarkozy launched the proposal for a new EU treaty, to replace the rescue mechanism for euro-countries in trouble and for the euro itself that was initiated by the European Council of May 7. The latter emergency mechanism will run out in 2013, so something more lasting will be needed, not to mention something more acceptable to the Bundesverfassungsgericht. Within two weeks of Deauville the European Council went along with the German-French initiative to create a permanent 'crisis resolution mechanism'.

It is possible to view these mechanisms as mere accessories to the monetary union rules. But they are probably better understood as modest though fundamental innovations. Back in 1991, Chancellor Helmut Kohl had insisted on political union as the bedrock for economic and monetary union. The other member states then turned a deaf ear on his plea. Recent events, however, have brought the message home with sufficient weight. At the time, no one knew what form Kohl's political union should take. Certainly, no one could have predicted that a financial crisis and a euro-crisis would provoke a treaty such as this as a first installment to the fulfillment of his wish. The 'crisis resolution mechanism', however, does embody a light form of fiscal solidarity among the euro-states and is, hence, a departure from the monetarist spirit of the Maastricht Treaty. This justifies a new treaty.

If 'Lisbon' was thought to be the treaty to end further amending treaties, at least for a good length of time, the call for a new treaty within a year of Lisbon's entry into force is significant in many ways. As is the practice in these editorials, let us convert the events into the currency of academic discussion, that is to say, into questions. Most interestingly these concern the subject of constitutional change in the Union.

Constitutional change is a great subject. The events provide all it takes to study it in the context of the EU. In order to get at the questions, let us first make some points about change and the constitution in general, then about constitutional change in the EU specifically. The questions will then appear as if summoned. 
Constitutions and change. Every constitution is necessarily bound up with change, in several ways. First, it is there to allow peaceful change of the community, by providing the ways of turning the potentially destructive conflict immanent in any community into constructive evolution. It is there, consequently, to make a community aware of its own development and responsible for it. The constitution channels the blind forces of natural (and technological) change into accepted, non-violent, constructive development.

Secondly, in order to channel social change, the constitution must itself be to some extent resistant to change. This is why a constitutional instrument is normally entrenched, that is to say difficult to amend. The same inertia also is needed for the constitution in its wider aspects. One of these is that which is often called 'the political constitution', i.e., the actual organisation of government and of its relationship with the people.

In both aspects mentioned, however, both as a legal instrument and as a structure of public authority, the constitution itself also needs to be subject to change. The legal instrument of government must be amendable and the actual organisation of government must be evolving. The constitution is somewhat like a river, channeling the waters from above on their way to the sea, but itself changing course, sometimes suddenly, often gradually. This is a third aspect of change concerning the constitution. The sudden change of a river compares to fundamental amendment of the constitution's legal instrument, as in France in 1958; the gradual changes of the river's course compare to the constitution's regular evolution through caselaw and practice or convention.

The EU and constitutional change. The subject of EU and constitutional change is special, first, because the Union has only an inchoate constitutional settlement and second, because the Union is of itself subject to relentless fundamental change. The European Union is a political community in progress. It is subject to more rapid and much more open development than its member states are, in terms of geography, in terms of scope and in terms of nature. In adopting these changes, however, the Union is itself gradually obtaining a greater capacity of channeling sources of conflict into constructive development.

Such is the pace of change of the Union that even the legal instruments at the basis of the Union's constitution, the founding treaties, are being overhauled more often and more thoroughly than most constitutional instruments of states. This is in utter defiance of the ultra-rigid procedure of change of Article $48 \mathrm{TEU}$, involving 'double unanimity' instead of, as in most states, only some form of qualified majority.

At the same time the Union's 'political constitution', its actual organisation of government, continues to evolve steadily, through not only the above primary 
legislation, but also through (organic) secondary legislation, judicial interpretation and constitutional practice or convention. This aspect of change, even if it includes the shocks of treaty change, is far more gradual than the formal treaty changes by themselves.

Questions on EU and constitutional change. The encompassing question seems to be about the role of constitutional doctrine of change in understanding and accounting for a political community which, unlike a state (witness the term 'state' alone), is not firmly established. The Union is a body politic which is and shall be essentially flawed, or defective, and into which consequently the drive of structural and constitutional evolution is somehow inbuilt more forcefully than in a state. It is one which is and will be essentially unfinished, unvollendet as the German language has it. This does not necessarily make it a lower constitutional animal. One may be reminded of German philosopher Helmut Plessner's definition of man as a 'Mangelwesen', as a being defined by its faults. The flaws drive the intelligence. The Union, then, would be a 'Mangelgemeinschaft'.

From there, the first punctual question arising is how, in its (single) constitutional being, a body such as the Union combines its constituent roots in the original founding authorities (the states) with those, autonomous, in its own institutions. These are the ECJ for interpretation; the political institutions for practice and convention. In other words, what is the actual relationship, under the urge of change, between the states as treaty masters and the European Council, the Council, the Parliament and the Court?

Secondly, there is the question as to how these shared constituent roots reflect not on constitutional change but on the day-to-day legislative and executive functioning of the Union's body politic. The coming constitutional settlement on the euro's financial support mechanism will not only consist of a new treaty. It will also take the form of secondary legislation and case-law.

A third, most fundamental, question is how this ever-unfinished constitutional situation, imperfect by definition, will ultimately allow the development of a sound relationship between the authorities and the people, a relationship which is at the heart of any constitutional settlement.

The last question (for now) sends us back to the one put in a previous editorial (in issue 1 of this year). It is: how to account for this incomplete and urged situation in a single and coherent constitutional reading?

Facts and rules to be established between 7 May 2010, the date of the original deal on the temporary fiscal support mechanism, and the ultimate settlement of the matter, will by themselves provide the research material needed for the study of the above questions. As a new part of the Union's constitution, this new settle- 
ment will again draw on all the sources of EU constitutional law, between treaty, (organic) secondary law, judicial rulings and institutional convention. It will even involve, of course, the national constitutional structures of the member states.

The new treaty is due to be ratified in 2013; give or take a few years. The subject is ripe to be picked up as of now by an interdisciplinary research group on EU constitutional law.

WTE/TWB 